\title{
Volunteer Support of English as an Additional Language (EAL) for Doctoral Students
}

\author{
Susan Carter \\ University of Auckland, New Zealand
}

s.carter@auckland.ac.nz

\begin{abstract}
English-as-an-additional-language (EAL) research students are a prized resource for universities desirous of doct oral output. Yet the task of writing a Ph.D. in a non-native language is Herculean. Besides wooing and welcoming EAL doctoral candidates, how do universities adequately support them in their labours as writers? Increasing numbers of EAL research students, increasing pressure on supervisors, and an increased urgency for timely completion cranks up the magnitude of EAL research writing challenges. This paper describes and evaluates one response: a writing support group for EAL doctoral students using volunteer native speakers.

The volunteerism model requires quite careful negotiation of the ethical issues. Whose responsibility is the volunteer support advice? How might the spectre of ghost writing be laid to rest? The model described has survived for several years now and has proved to be a sustainable community of practice; the article discusses the safety issues that arose in its construction and the factors that have contributed to its success, including our care around several institutional policies. A survey of the students who have made use of the programme shows what they expected to get from this and what they actually found from their experience, confirming the pedagogical underpinning. Evaluations from students inform this reflection. The article concludes by looking at this community of practice from several positions - student, supervisor, institution and volunteer, and my own as a tertiary learning advisor.
\end{abstract}

Keywords : doct oral support, English as additional language doctorates, volunteer support at tertiary institutions, internationalization.

\section{Introduction}

English-as-an-additional-language (EAL) research students are a prized resource for universities desirous of doct oral output. Universities wanting more annual doct oral completions (see confirmation of these phenomena in Carter, 2006; Powell, 2006; Walsh, 2006) compete for local and international students, with "strong growth in the numbers of postgraduate [EAL (English-as-anadditional-language)] students in the major education-provider countries" (Ryan \& Zuber-

Material published as part of this publication, either on-line or in print, is copyrighted by the Informing Science Institute. Permission to make digital or paper copy ofpart or all of these works for personal or classroomuse is granted without fee provided that the copies are not made or distributed for profit or commercial advantage AND that copies 1) bear this notice in full and 2) give the full citation on the first page. It is permissible to abstract these works so long as credit is given. To copy in all other cases orto republish or to post on a serveror to redistribute to lists requires specific permission and payment ofa fee. Contact Publisher@,InformingScience.org to request redistribution permission.
Skerritt, 1999, p. 3). Yet international students bring with them the challenges of writing about 80,000 words in competent academic prose in English when it is not their native language: the dissertation. The human stories behind doctoral internationalisation show that "Speakers of English as an additional language...still appear to be less empowered and more disabled in the institution" (Hutchings, 2006, p. 248); it is 
something of an understatement to note that "Such students often have difficulty meeting the demands of the kind of writ ing required of them in this particular genre" (Paltridge \& Starfield, 2007, p. 2). Resources for EAL students are seldom adequate (Strauss, Sachfleben, \& Turner, 2006), and EAL students may feel that they and their writing are somehow marginalised (Ali \& Kohun, 2007; Zamel, 1995). Doctoral drop-out rates have traditionally been high--as high as 50\% in some disciplines (Bair \& Haworth, 1999; McAlpine \& Norton, 2006; Mendoza, 2007)--and individuals who struggle with prose may lose hope and leave. In such cases, institutional loss is also personal tragedy; the cost of futility is high. Furthermore, writing frustrations oft en spill into supervisors' in-trays, yet supervisors are under increasing pressure in a changing university environment (Davies, 2003; Forgasz \& Leder, 2006; McGrail, Rickard, \& Jones, 2006). How might the responsibilities of a university be synchronised with its desire for fast doctoral completion rates from EAL students?

Most tertiary institutions are careful about recruitment, but even those EAL students who have ranked well in International English Language Testing System (IELT S) testing can find the size and complexity of their doctoral writing task disheartening. Many institutions, including my own, provide English for academic writing classes and nonetheless EAL researchers face an enormous challenge in the production of a dissertation. In New Zealand thePh.D. is commonly based on a dissertation only, so students do not get the same amount of practice within courses that the USA system entails. Many international students arrive at a new campus in a culturally different city to begin the lonely task of writing their dissertation.

My response as co-ordinat or of a Student Learning Centre doctoral programme has been to establish across-campus support from native English speaker volunteers to EAL doctoral students. This support group is called D.EAL (doctorates for EAL students) following on from a preexisting EAL undergraduate programme named R.EAL (Results for EAL students) that already existed in the Student Leaming Centre learning centre. Both international (Asian, European and Pacific Islander) and local students whose first language is not English made use of the support. These students self-identify as EAL. This support is not compulsory, so only candidates who feel they would like to develop their writ ing choose to attend. D.EAL has now operated for over four years, during which time we have sought to "maximis[e] the benefits of volunteerism and improve intergroup relations" (Karafant is \& Levy, 2004, p. 248). D.EAL provides a case-study of volunteerism that may be adaptable elsewhere.

Because the two groups who participated, doctoral students and retired volunteers, both benefitted in a symbiotic relationship, the support has proved to be a sustainable 'community of practice' (Wenger's 1998 term). D.EAL assumes that "support, encouragement and motivation are key benefits of writing interventions" (McGrail et al., 2006, p. 30), but more importantly, that one-toone work with writing is the best way for locating individual writing tics and thus enabling the writer to move forward and improve his or her skills.

However, my motive for wanting to publish on this support programme is to discuss the caveats as well as the possibilities, the potential for "juicy opport unities and wicked problems" (Cherry, 2005, p. 318). This paper discusses the inherent ethical risks of volunteer support and how they were negotiated. Survey data informs assessment of the limitations and benefits of D.EAL, also discussed from other perspectives - supervisor, institution and helper-including my own as a tertiary learning advisor.

\section{Background}

D.EAL support was prompted by an international doctoral student who said she was lonely. Intemational doctoral students come to a city where they lack support systems in order to do something like solitary confinement for three or four years (Ali \& Kohun, 2007; Aspland, 1999; Na- 
gata, 1999). Social isolation contributes to doctoral attrition, and doctoral programmes should address this elusive problem (Ali \& Kohun). But the international students who attended the first tentative meeting said that they had, collectively, not so much a need for social integration as a need for native English speaker help with their writing.

Jenny Buxton, a colleague who is an active member of the University of the Third Age (U3A: a collective of retired people who have active brains and want academic stimulation), suggested the U3A as a source of helpers and recruited about a dozen of them. Jenny as contact with the volunteers and a colleague who is trained in teaching English as a language then co-ordinated D.EAL with me and 'we' in the following refers to her and me.

The process has shown the benefits of bringing diverse groups together for mutual advantage; although liminal spaces, the borderlands between diverse groups, can be 'unhomely' (Bhabha's postcolonial term applied to academic advising by Manathunga, 2007), they are also rich with potential for a more holistic approach to education: 'The same unhomely space ... opens up a range of creative possibilities' (Manathunga, p. 32). Two needs are met by this pairing. EAL candidates have a practical need for help with writing a dissertation in a second or third language coupled with a need for int egration into a new community. U3A volunteers have a need for intellectual stimulation coupled with a desire to remain within a thinking community.

The individuals from U3A proved to be not just "any native speakers" but dynamic people. They relished the chance to voyeuristically watch new research grow. We do not advertise that the helpers are alumni or have educational qualifications, but it helps that they do. Most helpers are not trained language teachers (although two of our team of now about fifteen volunt eers are trained language teachers). Several have MA orPh.D.'s and several are retired professors. Finding the right pool of volunteers is probably crucial to successful volunteer support.

\section{Ethical Concerns}

There is an ethical issue of safety regarding responsibility. The volunteers are not required to have EAL teacher training: simply, the native speaker ear is loaned to non-native language production. If a doct oral student subsequently failed, could they take a case against us on the basis that they had got misleading advice from a volunteer? Where does that leave the volunteer who has no contractual responsibility with the institution? What if a volunteer was to prey upon a lonely and socially isolated international student: how could we ensure that we had control over the volunteers? Could we plan for safety, working in the borderlands between community and university, and would the legal advisors to the university accept that our strategies are adequate?

There is also the spectre of ghost-writing: a student who has poor literacy skills might get the thesis to read more plausibly than their own writing skills would allow, come through to completion, and leave with a doctorate but, nonetheless, illiterate in individual writing practice. Perhaps the biggest challenge has been ensuring that boundaries of authorship are carefully maintained. Academics know about authorship boundaries but could we ensure that the volunteers would respect them?

As a counterbalance, however, this article argues that another risk sharpens this issue, the risk of bias against EAL students. Within academia the boundaries regarding who authors language are always fluid and recognition of them is part of the implicit savvy (Parry's term) that students need to acquire (Parry, 2007, p. 29). We all learn the language of our own disciplines, for example, by listening to others, and acquire wider vocabularies from others. Alistair Pennycook (1996) applies post-modernist theory - death of the author, death of the subject — to the issue of plagiarism and dramatically announces, "We are not speaking subjects but spoken subjects, we do not create language but are created by it...the question then becomes not so much one of who authored a text but how we are authored by texts" (p. 209). The thesis is a defining text in terms of being multi- 
ply constructed as the author (authorised by the doctorate) uses supervisory, collegial, and literary advice and textual citation in the process of construction. The dissertation involves a lengthy process, and fairness is a vital issue, one difficult to ensure through the articulation of 'rules', as acknowledge d in a recent proposal for a bill of doctoral student rights (Schiederjans, 2007). To avoid the danger of 'othering' EAL students and excluding them from support deemed appropriate between native English speakers, effort should be made to bring EAL writers into the collegiality of the English speaking institution.

\section{Setting up Support}

EAL doct oral students had identified that what they needed most was help with the mechanics of their writing. This self-identified need confirmed qualitative research that at postgraduate level the difference between native and non-native speakers is great est at the level "of punctuation/spelling, accuracy of grammar, appropriateness of grammar... [and] smallest at the discourse level (quality of content, development of ideas and adequate treatment of topic)" (Casanave \& Hubbard, 1992, p. 38). Interviews with publishing EAL academics confirmed that almost all found "basic issues of grammar, article use, and punctuation" difficult (Buckingham, 2008, p. 5). Any well-educated native speaker, it seemed to us, would able to help with mechanics, even at doctoral level in an unfamiliar subject.

Word choice is something that native English speakers have expertise about. Quite often the lexicon will be 'wrong' because of the word's history; native English speakers are quick to spot words with unintended pejorative implications, for example, or words that are poetic rather than scholarly. Some words are judged dated or stilted by native speaker experience.

Specific help on actual writing also seemed more effective than a session that looked at principles of writing with examples that were not the students' own. Each volunteer settles down with their student and works slowly through the student's writing looking for any times when it is not fluent: articles and tenses are often an issue, but syntax and vocabulary can be too. Sentences are reconstructed in collaboration, and after a few sessions students are often identifying their own blind spots and improving their writing themselves, or moving on from one fault to concentrate on another. One student commented in the survey of their experience "I have actually progressed from one Deal session to another" and, as I show below, the same survey produced evidence that students are aware that their writing strategies advance beyond the task of improving just the writing scrut inised in the sessions.

The sessions are two hours long in which 10-20 pages or so of prose are reviewed. This time seemed long enough to make the sessions worth the journey into university for the helpers and not too long for concentration limits. Currently sessions occur fortnightly to meet the present demand from students. Students check the Doctoral Skills Programme (DSP) Website (where a fairly comprehensive suite of sessions are advertised, with D.EAL amongst many others) and book there to participate. Volunteers get a six-month's roster as it is drawn up and then also a reminder a few days before each session when we know how many students have booked that particular one.

We try to ensure that at each session there is an adequate number of volunteers so that the facilitator can float freely and is available should anyone want a second writ ing diagnosis. Occasionally, numbers do not tally and we are involved in working with students ourselves but usually we do some reading or revision of our own, keep an eye on proceedings, and give our opinion when it is sought, along with coffee, tea and biscuits. 


\section{Addressing Ethical Issues}

\section{Safety}

We pair helpers and students randomly, encouraging new partnering each time to reduce the risk that a volunteer will contribute too much to any given thesis. We discourage volunteers and students from meeting out of the session time, initially concerned to avoid dependency or bonding of a kind that could be problematic.

Students bring their writing in hard copy. Thus D.EAL work complies with The University of Auckland Policy on Third Party Editing (2008) which states that editors must work on hard copy and not electronically. Following a D.EAL session the research student will need to go away and make the changes penciled on their draft to their electronic document, reviewing suggestions, making decisions about them, and consolidating the point s covered.

We advertise that the volunteers are not subject specialists but offer only native English speaker advice, not content. This aligns us with The University of Auckland Policy on Third Party editing which spells out that an edit or should not contribute content but might consider:

\section{A Clarity}

- avoiding ambiguity, repetition and verbosity.

- the use of punctuation to ensure clarity of meaning and ease of reading.

\section{B Grammar and usage}

- the conventions of grammar and syntax in written English.

- words and their meanings (but not technical terms).

- the expression of numbers, dates, percentages, measurem ents and statistical data.

- the use of italics, capitalisation, hyphenation, symbols and shortened forms.

- the display of lists and quotations.

\section{Spelling and punctuation}

- spelling and punctuation (including British and American uses).

Although we take care to comply with the policy, the third party edit ors it addresses are professionals called in at the end of the process. Instead our support group offers help with the above issues at the draft stage of the process. We recommend that students might use this help before they submit their writing to their supervisors, freeing supervisors from surface level language work to focus on content.

\section{Guidelines}

We also give guidelines to all involved. Students and helpers see the advice we give to both groups. Following a description of how the group works and why we think it needs to exist, the guidelines read as follows:

\section{Guidelines for Helpers}

Stay focused on helping with writing; although the students and their research are interesting, try to restrict discussion to the writing in front of you. This focus helps the student the most. Work carefully and attentively to spot any language errors. Be aware that different disciplines have key terms, often common words used in a particular way. Understand that referencing system s and conventions vary according to discipline. Explain any correc- 
tions you suggest, such as when articles are missing or misplaced, or when tenses need altering. Ask for clarification when a sentence or passage is ambiguous, and offer advice on clarity. As a golden rule, offer writing suggestions always with the cautionary proviso that any lack of understanding may be due to lack of subject expertise rather than to the student's weak writing. The student (and of course their supervisor) is ultimately responsible for the presentation of the thesis. Choices are their responsibility. Refer students back to their supervisors when they are in doubt.

\section{Guidelines for Students}

Listen carefully, ask questions, and make sure you understand the advice. You are the expert in your subject; use your own subject-expert judgment on the feedback received. Consult with your supervisor for content, layout, and structural details; you and your supervisor always have the fin al authority. Politely keep your helper focused on helping you with the English language of your writing. Attend meetings frequently and use them as an incentive to productivity. Communicate with your helper and with us!

The guidelines comply with perhaps the most crucial principle of The University of Auckland Policy forThird Party Editing: that third party editors "may offer advice but the candidates themselves must choose which advice to accept." The authority that the candidates have over their work (even though they are being advised on the use of language) is emphasised.

In addition to these guidelines, each student fills in a form at each session on which they ident ify themselves and their helper for that session, what they hoped to achieve and whether they are satisfied that they did achieve it. We also use the standard DSP evaluation form, with D.EAL scoring 100\% in the strongly agree or agree cat egories in 2007 (the first year that we have evaluated the DSP) as to the usefulness of the session.

\section{Method of Gauging Student Experience of D.EAL}

I also conducted a survey to collect student views on their experience of D.EAL. An anonymous questionnaire (See the Appendix at the end of the paper.) sought to locate how D.EAL gave help and what its perceived limitations were. Invitation to participate was sent to 36 students who had used D.EAL; from this group, 13 replied.

\section{Limitations}

One limitation of the support is that, should all EAL students want to use our help weekly the logistics would be impossible. Among the limitations identified by students, four listed time ("Sometimes I have classes during that time", "limitations of time", "D.EAL only runs fortnightly", and "I usually could cover only one section each session of D.EAL"); getting session times to suit all is made more difficult with volunteer input. Although each pair talks quietly, the sessions are rather noisy; a student mentioned on the anonymous survey "noisy groups at times". The helpers do not always work as quickly and efficiently as students want and vary in terms of their individual strengths and weaknesses, with some being betterteachers than others.

Our concern to comply with the ethical issues addressed in our inst it ution policy also puts limitations on the support we provided; limitations we felt were appropriate. Five students of the thirteen who participated wanted more expert help than the volunteers provided:

- preferably all the volunteers are trained academically;

- I need more personal help from D.EAL; 
- it would be great if the helpers were those people having about similar background of expertise or someone familiar with the area of studies;

- lack of knowledge of the subject; and

- as a student from Engineering department I always expect helpers of D.EAL would have engineering background; however, it seems that few helpers are from the Engineering department.

Yet we feelthat it is important ethically that candidates do not get discipline specific help at D.EAL so that the language help is delineated from content help. Students get the benefit of a non-expert wanting to understand and thus pushing them to be clear and explicit, but do not get input from subject experts.

Similarly, we always pair people randomly although two students felt it would be better to stay with the same volunteer each time ("Changing oftutor every session which makes hard for next tutor to follow the writing"; "Continuing to work with the same helper couldn't be maintained"). Thus our concern with our institution's policy and our desire to comply with it creates limitations from the students' perspective.

Some students would prefer professional editing at the submission stage to be provided without cost, something they are unlikely to get. Thus one set of limitations relates to resources. One student identified that D.EAL can be a waste of time for proficient writers: "If your English is at a very good level already it is difficult to improve in D.EAL sessions because oft en the session partners are comparing or rather have compared my English to others students and their difficulties. I also found that some partners have enjoyed a good conversation more that actually working on the text itself." We have seen volunteers who wander from the task in hand to enjoy listening and talking. Some students find this feels friendly, but for others it is irritating and timeexpensive.

\section{Pedagogy and Community of Practice}

D.EAL's volunteer support is one response to EAL students' perception of the demands of academic performance as being "embedded in the local culture" and "a potentially complex and conflictual process of negotiation rather than as a predictable, unidirectional process of encult uralisation" (Morita, 2000, p. 278). Students invited in the survey to give "other thoughts about D.EAL" gave rather thinner responses than expected; their comments did not go into details about frustration, culture or pedagogy. They were mainly quite simply positive about D.EAL:

- Very useful program. It was very helpful for me.

- D.EAL is really one of the best program/services offered by the university. Keep up the good work.

- All the helpers I have had (names two) are wonderful people!

- I have learned to communicate well and also this program has helped me with improving my listening skills.

- Good. Provides support for Ph.D. students and this programme should be continued in the future.

The survey failed to get evidence for observation through conversations that EAL students find it hard to approach their supervisor about their frustration with language when their language is also a cause of frustration to the supervisor. Although none of the students identified that they felt more comfortable asking volunteers rather than their supervisors about language details, one 
noted that "the sessions and the friendships which I developed were helpful". Most neither expected nor got conversation skills and friendship, but some found they did get these when they had not expected them. Those who identified as finding 'friendship' I think saw the term as an approximation of the positive learning environment created in a community of practice that works across age and cultural boundaries and the walls of the university.

The responses to the before and after survey asking what students expected to get from D.EAL and what they found they actually got were charted (shown in Figure 1). The chart has four categories: expected and got; expected and did not get; did not expect and did not get; and did not expect but got. On this chart "non-technical account" is an abbreviation for "a way to think about your work by describing it to non-academics." Some of the results are predictable and straightforward: for example, generally they expected and got help with proof-reading and grammar. The Student Leaming Centre that hosts D.EAL is adamant that we do not do proof-reading, but it is not surprising that it occurs as a by-product to teaching deeper level writing skills.

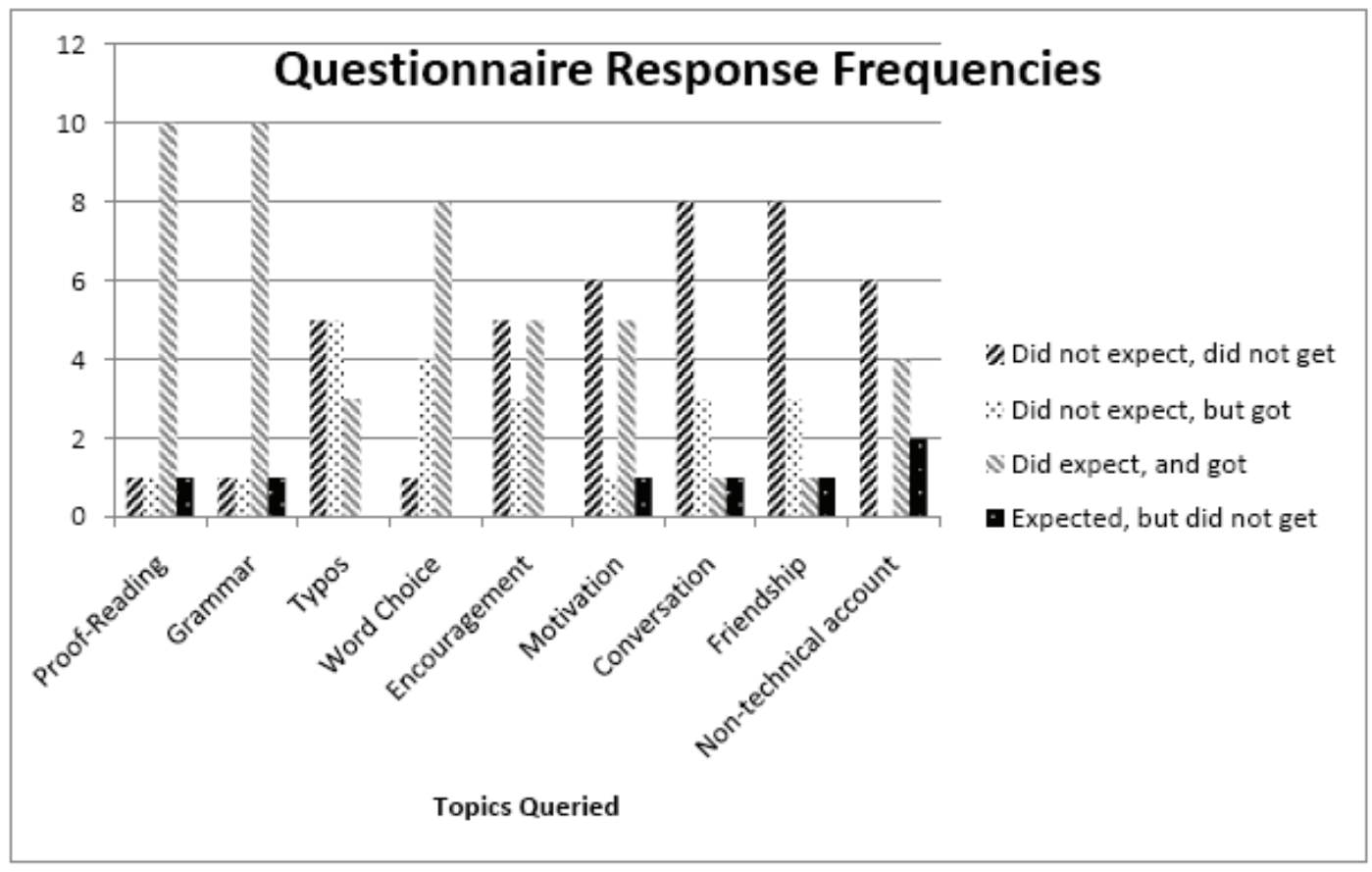

\section{Figu re 1: Students' responses to what they expected and what they actually got from the support programme}

More calibration could be done with the issues behind these results, and this exploratory survey can be regarded as one that opens up issues rather than giving finite answers. One cat egory of participant response endorses the truism that we create the world with our own att it udes: almost an equal number did not expect to get encouragement and did not get it as those who expected and got encouragement.

Pleasingly students reported that the sessions enabled them to improvetheir writing skills. Students were asked to indicate on a scale of one to seven (where seven is most useful) how useful D.EAL was in terms of improving the written work they brought along; teaching improved writing skills; improving English language speaking and listening skills; and maintaining motivation. Unsurprisingly, 'improvement to the writ ing brought along' scored highest with 67, but 'improved writing skills' was not far behind with 62. 'Motivation' scored 57 and speaking and 'listening skills' 47 . Students recognised that writing skills are improved almost as significantly as the piece of writing under analysis. 
The improvement of writing brought along and more importantly of writing skills helps supervisors as well as the students themselves. It is not new to note that "academics now face intolerably high teaching loads, suffer increased stress, and have little time for research" (Forgasz \& Leder, 2006, p. 1). Others have reported this too in different contexts such as a feminist one (Acker \& Armenti, 2004), or with concern for future academics facing increased pressure (Aust in, 2002) or as a reason for promoting time management (Kearns \& Gardiner, 2007). Some supervisors direct students to us, grateful for assistance.

Improvement to writing furthers institutional desire for research 'output.' That the language of the conveyor belt has advanced into the ivory tower bespeaks the fact that "For better or worse for better and worse, really. - - higher education is being transformed by both the power and the ethic of the marketplace" (Kirp, 2003, p. 2). Ryan \& Zuber-Skerritt (1999) give figures of the large amounts of cash involved in internationalised education and address the main issues (Ryan \& Zuber-Skerritt, pp. 4-6). As a small country example, recently The University of Auckland's Vice-Chancellor pointed out that:

International education makes a major contribution to the New Zealand economy-it is now one of our largest export activities, generating more foreign exchange revenue (nearly $\$ 2$ billion in 2005) than the fishing (\$870 million a year) and wine (\$611 million) industries. The jobs of a great many New Zealanders rely on the fin ancial contribution that international students, their families and their governments make to this country through international education. (McCutcheon, 2007, p. 3)

Doctoral completions enhance budget as well as reputation in the competition for Performance Based Research Funding given out by the New Zealand government. Quite simply, there are fiscal reasons for looking for ways to support int ernational research students with their thesis writing task. Yet, universities eager for increased post graduate research activity and actively wooing internat ional students also have responsibilities. "The onus of responsibility [for research supervision] lies not only with the supervisor, but also with the institution in which the student will research" (Knight, 1999, p. 97). Generic support from the Student Learning Centre or a similar central group can help towards fulfilling this responsibility.

Another benefit has been to the volunteers, who are thus linked to the research community. Volunteer help benefits volunteers at school level (Adams \& Taylor, 1980; Hickman, 1972; Mulligan, 1979), but it is also a good way to build community links for international research students while simultaneously enriching the lives of retired citizens: "volunt eering can serve goals related to academic, social and personality development" (Karafant is \& Levy, 2004, p. 236). The volunteers' desire for participation is crucial to the pedagogy of the support.

The sessions work because students relish the humility and interest volunteers show towards their topic. Volunteers' keenness to have things explained and grat itude that they can be involved make them less threatening than an awesome supervisor under pressure (see confirmation of student reluctance to trouble busy supervisors in Paltridge \& Starfield, 2007, p. 31). Recent educational theories propound "notions of the research education environment as pedagogical space involving multiple and overlapping notions of communit ies of practice ... in contrast to the conventional focus on individual supervision relationships as the privileged if not the only acknowledged site of pedagogy" (Boud \& Lee, 2005, p. 503). EAL research support with carefully chosen volunteers and guidelines is an example of what this might look like in practice. The look is promising.

Although I advance the hard-nosed business of the university in its push for 'output,' I see "higher education as a site for personal engagement, transformation, and change through individual development" (Walker, 2006, p. 1). Volunteerism requires care but opens up the possibility of doing more to sustain the EAL research experience. 


\section{Acknowledgments}

I need to thank Mart in Putterill for his advice about protocol, acknowledge Jenny Buxton's inspiration and her value as a co-convener, and thank Barbara Grant for her insights with this paper.

\section{References}

Acker, S., \& Armenti, C. (2004). Sleepless in academia. Gender and Education, 16(1), 4-24.

Adams, P. K., \& Taylor, M. K. (1980). Volunteer help in the classroom. Education Unlimited, 2(1), 26-27.

Ali, A., \& Kohun, F. (2007). Dealing with social isolation to minimize doctoral attrition: A four stage framework. International Journal of Doctoral Studies, 2, 33-49. Retrieved from http://ijds.org/Volume2/IJDSv2p033-049Ali28.pdf

Aspland, T. (1999). 'You learn round and I learn square:' Mei's story. In Y. Ryan \& O. Zuber-Skerritt (Eds.), Supervising postgraduates from non-English speaking backgrounds (pp. 25-39). Buckingham: Society for Research into Higher Education \& Open University Press.

Austin, A. E. (2002). Creating a bridge to the future: Preparing new faculty to face changing expectations in a shiffing context. The Review of Higher Education, 26(2), 119-144.

Bair, C. R., \& Haworth, J. G. (1999, Nov. 18-21). Doctoral student attrition and persistence: A metasynthesis of research. Paper pres ented at the 24th Annual Meeting of the Association for the Study of Higher Education, San Antonio, Texas.

Boud, D., \& Lee, A. (2005) 'Peer learning' as pedagogic discourse for research education. Studies in Higher Education, 30(5), 501-516.

Buckingham, L. (2008). Development of English academic writing competence by Turkish scholars. International Journal of Doctoral Studies, 3, 1-18. Retrieved from http://ijds.org/Volume3/IJDSv3p001018Buckingham29.pdf

Carter, S. (2006). Reflections on best practice: A kiwi perspective on 'new dimensions for doctoral programmes in Europe'. In C. Fraser and L. Ayo (Eds.) Anchoring our practice: Perspectives, partnerships, projections (pp. 21-34). Tauranga, New Zealand: ATLAANZ.

Casanave, C. P., \& Hubbard, P. (1992). The writing assignments and writing problems of doctoral students: Faculty perceptions, pedagogical issues, and needed research. English for Specific Purposes, 11(1), 3349.

Cherry, N. L. (2005). Preparing for practice in the age of complexity. Higher Education Research and Development, 24(4), 310-320.

Davies, B. (2003). Death to critique or dissent? The policies and practices of new managerialism and of 'evidence-based practice'. Gender and Education, 15(1), 91-103.

Forgasz, H. J., \& Leder, G. C. (2006). Academic life: Monitoring work patterns and daily activities. Australian Educational Researcher, 33(1), 1-22.

Hickman, C. W., Jr. (1972). Volunteer help: Resource in instruction? SO - Educational Leadership. 30(2), 121-124.

Hutchings, C. (2006). Reaching students: Lessons from a writing centre. Higher Education Research and Development, 25(3), 247-261.

Karafantis, D. M., \& Levy, S. R. (2004). The role of children's lay theories about the malleability of human attributes in beliefs about and volunteering for disadvantaged groups. Child Development, 75(1), 236250 .

Kearns, H., \& Gardiner, M. (2007). Is it time well spent? The relationship between time management behaviours, perceived effectiveness and work-relat ed morale and distress in a university context. Higher Education Research and Development, 26(2), 235-247. 
Kirp, D. L. (2003). Shakespeare, Einstein and the bottom line: The marketing of higher education. Cambridge, MA, and London, England: Harvard University Press.

Knight, N. (1999). Responsibilities and limits in the supervision of NESB research students in the Social Sciences and Humanities. In Y. Ryan \& O. Zuber-Skerritt (Eds.), Supervising postgraduates from nonEnglish speaking backgrounds (pp. 93-100). Buckingham: Society for Research into Higher Education and the Open University Press.

Manathunga, C. (2007). 'Unhomely' academic developer identities: More post-colonial explorations. International Journal for Academic Development, 12(1), 25-34.

McAlpine, L., \& Norton, J. (2006). Reframing our approach to doctoral programes: an integrative framework for action and research. Higher Education Research and Development, 25(1), 3-17.

McCutcheon, S. (2007). From the Vice-Chancellor. Ingenio: The University of Auckland Alumni Magazine (Spring), 3.

McGrail, M. R., Rickard, C. M., \& Jones, R. (2006). Publish or perish: a systematic review of interventions to increase academic publication rates. Higher Education Research and Development, 25(4), 19-35.

Mendoza, P. (2007). Academic capitalism and doctoral student socialization: A case study. Journal of Higher Education, 78(1), 71-96.

Morita, N. (2000). Discourse socialization through oral classroom activities in a TESL program. TESOL Quarterly, 32(2), 279-310.

Mulligan, D. (1979). Effective involvement of school volunteers. Partners for the 80's: Handbook for teachers (Guides - Non-Classroom): National School Volunteer Program, Inc., Alexandria, VA.; National Education Association, Washington, DC.

Nagata, Y. (1999). 'Once I couldn't even spell "PhD student", but now I are one!': Personal experiences of an NESB student. In Y. Ryan \& O. Zuber-Skerritt (Eds.), Supervising postgraduates from non-English speaking backgrounds (pp. 15-24). Buckingham: Society for Research into Higher Education \& Open University Press.

Paltridge, B., \& Starfield, S. (2007). Thesis and dissertation writing in a second language: A handbookfor supervisors. London: Routledge.

Parry, S. (2007). Disciplines and doctorates (Vol. 16). Netherlands: Springer.

Pennycook, A. (1996). Borrowing others' words: Text, ownership, memory, and plagiarism. TESOL Quarterly, 30(2), 201-230.

Powell, S. (2006, July 6-8). Models for doctorates in Europe. Paper presented at the New Dimensions in Doctoral Programmes in Europe: Training, Employability and the European Knowledge Agenda: The UK Council for Graduate Education Summer Conference, Florence, Italy.

Ryan, Y., \& Zuber-Skerritt, O. (1999). Supervising non-English speaking background students in the globalized university. In Y. Ryan \& O. Zuber-Skerritt (Eds.), Supervising postgraduates from non-English speaking backgrounds (pp. 3-11). Buckingham: Society for Research into Higher Education and the Open University Press.

Schiederjans, M. (2007). A proposed Ph.D. student bill of rights. International Journal of Doctoral Studies, 2, 1-8. Retrieved from http://ijds.org/Volume2/IJDSv2p001-008Schniederjans22.pdf

Strauss, P., Sachfleben, A., \& Turner, E. (2006). Talkback: Empowering EAL thesis writers. In J. A. Van Rij-Heyligers (Ed). Intercultural communications across university settings: Myths and realities (pp. 174-188). Auckland, Communication Skills in University Education.

University of Auckland Policy on Third Party Editing. (2008). Retrieved January 5, 2008 from http://www. postgrad.auckland. ac.nz/uoa/for/postgradstudents/administration/policiesguidelines/doctoral policies.cfin\#Policy $\% 20$ on $\% 20$ Third $\% 20$ Party $\% 20$ Editing $\% 20 \& \% 20$ ProofReading $\% 20 \mathrm{o} \% 20 \mathrm{Theses} \% 20 \& \% 20$ Dissertations 
Walker, M. (2006). Higher education pedagogies: A capabilities approach. Maidenhead: Open University Press.

Walsh, P. (2006, July 6-8). Career development of doctoral candidates and post-docs: Recent developments in Ireland. Paper presented at the New Dimensions in Doctoral Programmes in Europe: Training, Employability and the European Knowledge Agenda: The UK Council for Graduate Education Summer Conference, Florence, Italy.

Wenger, E. (1998). Communities of practice: Learning, meaning and identity. Cambridge: Cambridge University Press.

Zamel, V. (1995). Strangers in academia: The experiences of faculty and ESL students across the curriculum. College Composition and Communication, 46(4), 506-521.

\section{Appendix}

\section{Questionnaire on D.EAL for Doctoral EAL Students}

A) Approximately how many times have you attended the D.EAL support sessions?
$1-5$
$5-10$
$10-15$
15-20 morethan 20

B) What did you expect to get from D.EAL be fore you went to a D.EAL session? Tick any of the following that accurately express your expectations.

1. Proof-reading

2. Help with grammar

3. Picking up typos

4. Help with word choice

5. Encouragement

6. A way to stay motivated

7. A way to practice talking to kiwis

8. Friendship with kiwis

9. A way to think about your work by describing it to non-academics

10. Any other expectations?

C) What do you think you actually got after you went to D.EAL? Tick any of the following that accurately express what you got help with from D.EAL.

1. Proof-reading

2. Help with grammar

3. Picking up typos

4. Help with word choice

5. Encouragement

6. A way to stay motivated

7. A way to practice talking to kiwis

8. Friendship with kiwis

9. A way to think about your work by describing it to non-academics 
10. Any other help?

Answer the following questions thinking about how D.EAL has worked for you. On a scale of 1 to 7 where 1 is no use and 7 is extremely useful,

A) The written work you brought to D.EAL

How useful was D.EAL for improving the written work you brought al ong? P lease circle one No use extremely useful 1 $2-3$ 4 5 $6 \quad 7$

B) The writing skills you learned at D.EAL

How useful was D.EAL for teaching you to improve your writing skills? Please circle one No use extremely useful

$\begin{array}{llllllll}1 & 2 & 3 & 4 & 5 & 6 & 7\end{array}$

C) The con versation skills you learned at D.EAL

How useful was D.EAL for improving your English lan guage speaking an dlistening skills? Please circle one

No use extremely useful

$\begin{array}{llllllll}1 & 2 & 3 & 4 & 5 & 6 & 7\end{array}$

D) The motivational su pport from D.EAL

How useful was D.EAL for keeping you motivated in your dis sertation writing? P lease circle one

1 2 3 4 5

6 7

E) What have you found to be limitations of D.EAL?

Any other thoughts on D.EAL?

\section{Biography}

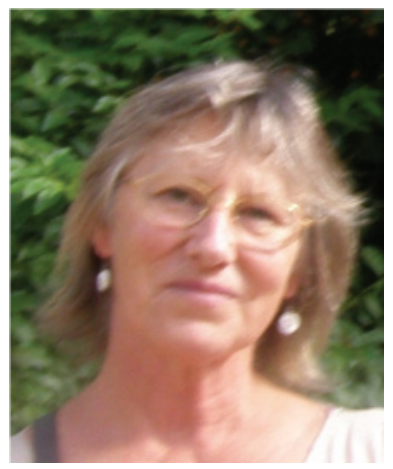

Su san Carter has coordinated the Doct oral Program at the University of Auckland Student Learning Centre for the last five years. She completed her BA and MA at the University of Auckland, New Zealand, and her English literature Ph.D. at the University of Toronto, Canada, in 2001. She has published several articles on Medieval and Renaissance English literature, and in Higher Education has published on a pedagogy method SHNID (2006); punctuation (2007); a New Zealand perspective of the European Union Bologna process regarding doctoral students (2007); examiner comments on the doctoral examination process (2008); tert iary learning advisor ident ity (2008) and a mnemonic approach to the structure of the thesis (2009). Having almost cleared her desk of work on literature following on from her doctorate she focuses her research interest on higher education, particularly on doct oral support, process and best practice. 